\title{
System Design of MPPT Incremental Conductance on Zeta Converter Connected Solar Panel
}

\author{
Jendra Sesoca \\ Department of Electrical \\ Engineering \\ University of Brawijaya \\ Malang, East Java, \\ Indonesia
}

\author{
Bambang Siswojo \\ Department of Electrical \\ Engineering \\ University of Brawijaya \\ Malang, East Java, \\ Indonesia
}

\author{
Ponco Siwindarto \\ Department of Electrical \\ Engineering \\ University of Brawijaya \\ Malang, East Java, \\ Indonesia
}

\begin{abstract}
MPPT Incremental Conductance algorithm has a function to obtain maximum power points on a solar panel. This MPPT Incremental Conductance works based on the P-V curve of the solar panel. In order to obtain better power results, the MPPT Incremental Conductance system will be connected to the zeta converter. The zeta converter is a DC-DC converter that is a development of the SEPIC converter. This converter can also produce good efficiency. In this research will compare the power generated with 2 different methods, solar panels connected with zeta converter without using MPPT Incremental Conductance and solar panels connected zeta converter using MPPT Incremental Conductance. The result of the research obtained is that solar panels connected to zeta converter using MPPT Incremental Conductance can produce better power than not using MPPT Incremental Conductance.
\end{abstract}

Keywords: Incremental Conductance, MPPT, Zeta, Converter, Solar Panel

\section{INTRODUCTION}

Global warming has increased and created global concern. Greenhouse gas emissions such as carbon dioxide and carbon monoxide are the main causes of global warming. The contribution of these gases comes from the use of coal used as a conventional source of electricity. Conventional power sources are still used as electricity providers for electricity use. The demand for electricity usage that is currently increasing rapidly certainly raises concerns about global warming. Renewable energy sources play an important role as a provider of electrical energy.

Solar energy is one of the renewable energy sources that can be utilized. At this time solar energy has an important role in the world because the energy is unlimited, clean and environmentally friendly. The solar energy can be converted into electricity using solar panels. Solar panels are a technology that can convert sunlight into DC electricity. The electricity generated by solar panels is affected by the large intensity of sunlight.

The main problem of solar panels is the output produced has a small power efficiency value. The impact of the efficiency of small solar panels affects the output power of these solar panels. Therefore, it is necessary to develop and research to improve the efficiency of solar panel power.

MPPT Incremental Conductance method is a simple method but has the advantage to find a good maximum power point despite changes in conditions on solar panels. Changes in conditions such as changes in environmental conditions, such as irradiance and temperature entering the solar panels [1] (Tekeshwar, 2014). The MPPT Incremental Conductance method will then be used in the DC-DC converter. It is enabled to control the work of solar panels in order to maintain the maximum power point that has been obtained.

The Zeta converter is a development of the DC-DC converter, where the Zeta converter generates low 
voltage ripples and low current ripples. The Zeta converter can also raise and lower the output voltage at a certain level. The output in the Zeta converter produces the same voltage polarity as its input voltage [2] (Soedibyo, 2015).

Research on comparison analysis on several converters include Cuk, SEPIC and Zeta converters. In this research showed that Zeta converter has a good performance from other converters. In the Zeta converter it produces an output voltage that is not reversed, rise-time and settling-time faster than the Cuk and SEPIC converters. [3] (N. Karthick, 2015). The next research is to conduct a research study on SEPIC, Luo and zeta converters. The purpose of this researcg was to find out the efficiency produced in each converter. The results showed that Zeta converter produce the best efficiency compared to SEPIC and Luo converters [4] (Niranjana, 2019). The next research is research on Buck Boost, Zeta and SEPIC converters. The purpose of this research is to find out the exact type of converter used for MPPT systems. The results showed that Zeta converter produce a stable response and produce small ripples of voltage and ripple current. Small voltage ripple and current ripple values will be well used in the process of determining the maximum power point by using MPPT [5] (Prashanth, 2020). The next research is research on duty cycle control in Cuk converter with several different MPPT. MPPT used is Peturb and Observe with Incremental Conductance. The results showed that the output on the converter using Incremental Conductance provides a better accurate rate for tracking maximum power points than using MPPT Peturb and Observe [6] (Takeshwar, 2014).

Based on the description of previous research, a research converter zeta conducted using MPPT Incremental Conductance connected solar panels.

\section{RELATED WORK}

Incremental Conductance is an MPPT algorithm that can track the maximum power point value of solar panels. This MPPT system obtains the maximum power point of the solar panel instead of working dynamically following the motion of the direction of the sun, but the MPPT system is working through the approach characteristic of solar panels. In this research using Zeta converter because it produces good power efficiency. The data to be researched are the intensity of light and

WWW.ijcat.com temperature as solar panel inputs, as well as the value of batteries attached to the Zeta converter. Furthermore, the data that has been obtained in this research will be analyzed. The data observed is the output of zeta converter in the form of voltage, current, and power.

\section{METHOD}

\subsection{Photovoltaic}

Photovoltaic is a technology that function to convert solar radiation into electrical energy directly. The PV is usually packaged in a unit called a module. In a solar module consists of many solar cells arranged in series or parallel. While solar cell is a semiconducting element that can convert solar energy into electrical energy on the basis of photovoltaic effects

[7] (Nelly Safitri, Teuku Rihayat, 2019).

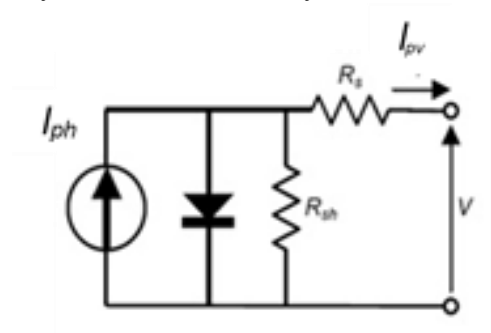

Figure 1. Equivalent Circuit of Photovoltaic

Model mathematic of PV module as shown below Equation. 1.

$I=I_{p h}-I_{S}\left(\exp \frac{q\left(V+I R_{S}\right)}{N K T}-1\right)-\frac{\left(V+I R_{S}\right)}{R_{s h}}$

Where, $\mathrm{I}_{\mathrm{ph}}$ is the photocurrent, $\mathrm{I}_{\mathrm{s}}$ saturation current, $\mathrm{q}$ is the electronic charge, $\mathrm{N}$ is the diode factor, $\mathrm{K}$ is the Boltzmann's constant, $\mathrm{T}$ is the junction temperature in Kelvin, $\mathrm{V}$ is the voltage across the diode, $R_{s h}$ is the shunt resistance and $R_{s}$ is the series resistance [8] (Nema, S. and Nema. ). The output characteristic of $\mathrm{P}-\mathrm{V}$ module with the different irradiance and temperature value shown in Figure 2.

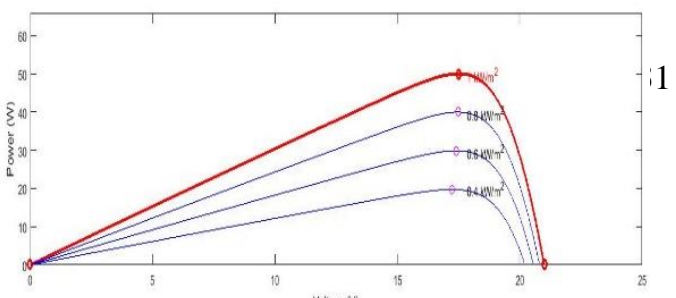


Figure 2. Characteristic of P-V Module

\subsection{Zeta}

The Zeta converter is a development of a Buck-Boost converter that can produce low output voltage ripples. The Zeta converter works like a Buck-Boost converter that can raise and lower incoming DC voltage. In addition, the output voltage polarity of the Zeta converter is not reversed. The Zeta converter consists of diode, inductor, capacitors and MOSFET. MOSFET component serves as a reasoning that is influenced based on PWM duty cycle value that enters at the foot gate MOSFET [9] (N. Sowmya Smitha Raj \& B. Urmila, 2013)

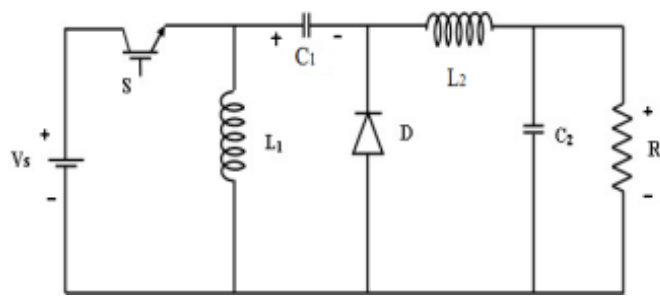

Figure 3. Zeta Converter

The design of the Zeta converter can be obtained from the following formula. The value duty cycle is given as Equation 2.

$D=\frac{V_{O}}{V_{\text {in }}+V_{o}}$

The inductor value is calculated as Equation 3.

$L_{1}=L_{2}=L=\frac{1}{2}\left(\frac{V_{\text {in }} D}{\Delta I_{L} \times f_{s w}}\right)$

The capacitor $\mathrm{C} 1$ and $\mathrm{C} 2$ value are calculated as Equation 4 and Equation 5.

$C_{1}=\frac{D}{\Delta I_{L} \times V_{i n} \times f_{s w}}$

$$
C_{2}=\frac{D}{8 \times \Delta V_{C 2} \times f_{s w}}
$$

\subsection{Incremental Conductance}

The Incremental Conductance method works based on the gradient of the P-V curve or the characteristic P-I curve of the solar cell. The maximum working point of solar cells is at different voltage values in each different condition called $\mathrm{V}_{\text {MPP. }}$. The P-V characteristic of solar cells is the function of power to voltage. Reaches the maximum point when the gradient is zero. [10] (Bharti, M., Kumar, U. 2017). Incremental Conductance (IC) works based on the gradient of the P-V curve or the characteristic P-I curve of a solar cell in search of a Maximum Power Point (MPP) value. Maximum Power Point (MPP) condition is a position where maximum power is obtained in MPPT system. The flowcharts of Incremental Conductance shown in Figure 4. The current and the voltage of PV module are read by MPPT controller. Duty cycle of the converter is increased if Equation 7 is satisfied and duty cycle of the converter is decreased if Equation 8 is satisfied. Duty cycle will no change if Equation 6 is satisfied and MPP has been achieved.

$\frac{d I}{d V}=-\frac{I}{V}$
$\frac{d I}{d V}<-\frac{I}{V}$
$\frac{d I}{d V}>-\frac{I}{V}$

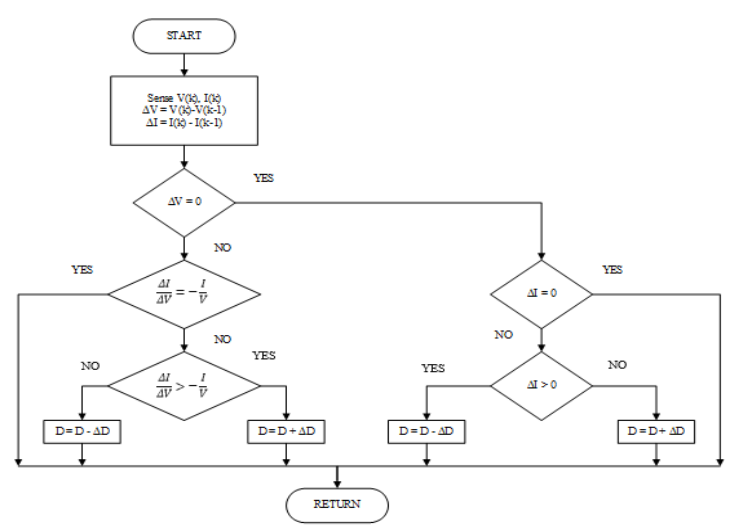

Figure 4. Flowchart Incremental Conductance 


\subsection{Proposed Zeta and Incremental Conductance}

In Zeta converters are connected solar panels using MPPT Incremental Conductance system. MPPT Incremental Conductance serves to find the value of voltage point $\left(\mathrm{V}_{\mathrm{MP}}\right)$ and maximum current ( $\left.\mathrm{I}_{\mathrm{MP}}\right)$ of solar panels.

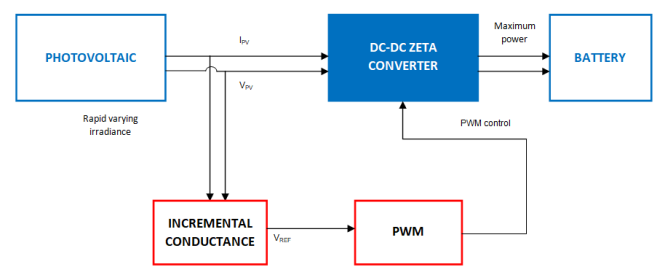

Figure 5. Zeta and MPPT Incremental Conductance

\section{RESULT AND DISCUSSION}

The Zeta converter generates maximum solar panel power by using MPPT Incremental Conductance. The output of the Zeta converter can be shown in Figure 6 . The results showed that zeta converter using MPPT Incremental Conductance can increase output power.

Table 1 shows the comparison of power output generated by Zeta converter using MPPT Incremental Conductance and without using MPPT Incremental Conductance.

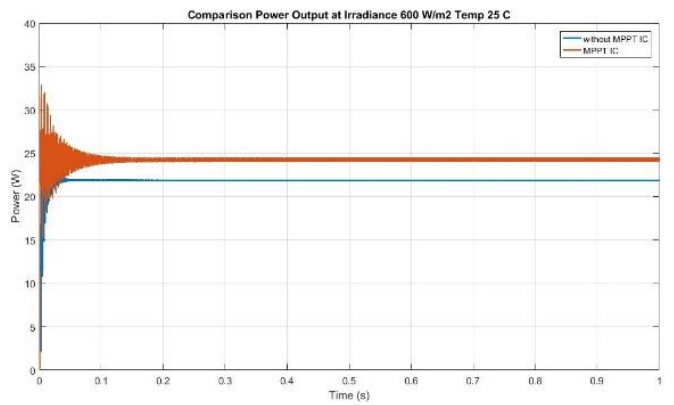

Figure 6. Output Power System at Irradiance 600 $\mathrm{W} / \mathrm{m}^{2}$ and Temperature $25^{\circ} \mathrm{C}$

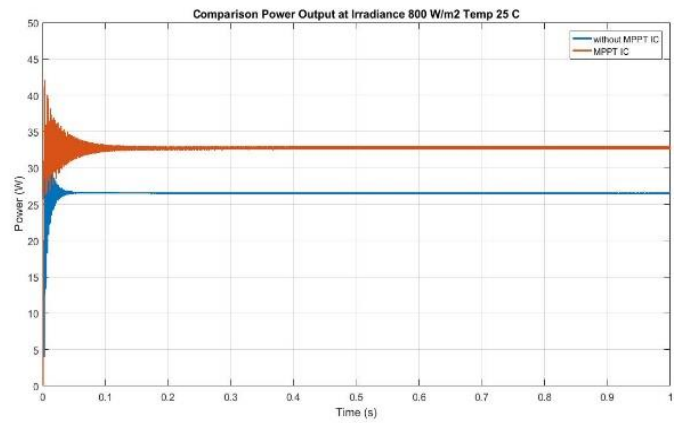

Figure 7. Output Power System at Irradiance 800 $\mathrm{W} / \mathrm{m}^{2}$ and Temperature $25^{\circ} \mathrm{C}$

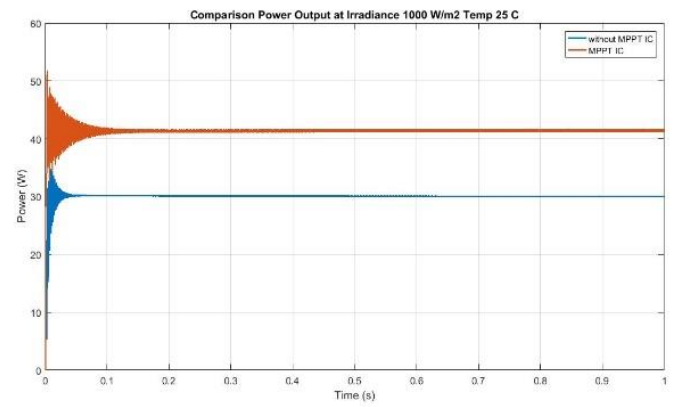

Figure 8. Output Power System at Irradiance 1000 $\mathrm{W} / \mathrm{m}^{2}$ and Temperature $25^{\circ} \mathrm{C}$

Table 1. Result Comparison

\begin{tabular}{|c|c|c|c|}
\hline \multirow{2}{*}{ MPPT } & \multicolumn{3}{|c|}{ Average Output Power $(\mathbf{W})$} \\
\cline { 2 - 4 } & Irradiance & Irradiance & Irradiance \\
& 600 & 800 & 1000 \\
& $\mathrm{~W} / \mathrm{m}^{2}$ & $\mathrm{~W} / \mathrm{m}^{2}$ & $\mathrm{~W} / \mathrm{m}^{2}$ \\
\hline Non MPPT & 21.76 & 26.40 & 29.97 \\
\hline Mppt & 24.20 & 32.68 & 41.29 \\
\hline
\end{tabular}




\section{CONCLUSION}

Design of Zeta converter using MPPT Incremental Conductance for maximum power point tracking in photovoltaic has been presented.

The results of this research showed that Zeta converters using MPPT Incremental Conductance can find a good maximum power point. The power generated by Zeta converter with MPPT Incremental Conductance is better than without using MPPT Incremental Conductance.

\section{ACKNOWLEDGMENTS}

This research was technically supported by Brawijaya University 2020. The first author would like to thanks to Dr. Ir. Bambang Siswojo, MT and Dr. Ir. Ponco Siwindarto,M.Eng.Sc from Brawijaya University for encouraging and giving best effort to finish in this research.

\section{REFERENCES}

[1] Tekeshwar, P.S., Dixit, T.V. 2014. Modelling and Analysis of Peturb and Observe and Incremental Conductance MPPT Algorithm for PV Array Using Cuk Converter. IEEE.

[2] Soedibyo, Budi Amri, Mochamad Ashari. 2015. The Comparative Study of Buck Boost, Cuk,SEPIC and Zeta Converter for Maximum Power Point Tracking Photovoltaic Using P\&O Method. Int. Conference on Information Technology, Computer and Electrical Engineering.

[3] N. Karthick, I.Manoj, and K.V.Kandasamy, 2015. Performance Characeteristic of Various DC-DC Converter for Efficient Solar Energy Conversion for Automobile Applications. Journal of Chemical and Pharmaceutical Sciences.

[4] Niranjana Siddharthan, Baskaran Balasubramarian, 2019. Performance Evaluation of SEPIC, Luo and Zeta Converter.
International Journal of Power Electronics and Drive System.

[5] Prasanth N.A., Anirudha K.S., B.Manjunath. 2020. Comparative Study of Buck Boost, Zeta and SEPIC DC-DC Converters for Maximum Power Point Tracking Application in PV System. Journal of Emerging Technologies and Innovative Research.

[6] Tekeshwar, P.S., Dixit, T.V. 2014. Modelling and Analysis of Peturb and Observe and Incremental Conductance MPPT Algorithm for PV Array Using Cuk Converter. IEEE.

[7] Nelly Safitri, Teuku Rihayat, 2019. Buku Teknologi Photovoltaic. Yayasan Puga Aceh Riset.

[8] Nema, S., Nema, R.K., Agnihotri, G. 2010. Matlab Simulink based Study of Photovoltaic Cells Modules Array and Their Experimental Verification. International Journal of Energy and Environment (IJEE), Vol 1, Issue 3, pp.487500 .

[9] N. Sowmya Smitha Raj \& B. Urmila, 2013. Zeta Converter Simulation For Continuous Current Mode Operation. International Journal of Advanced Research in Engineering and Technology (IJARET), Volume 10, Issue 1.

[10] Bharti, M., Kumar, U. 2017. Virtualization and Simulation of Incremental Conductance MPPT Based Two Phase Interleaved Boost Converter using Simulink in MATLAB. International Journal for Technological Research in Engineering (IJTRE), Volume 4, Issue 9. 